\title{
African voters indicate lack of support for climate change policies
}

\author{
Nick Obradovich ${ }^{\mathrm{a}, \mathrm{b}, \mathrm{c}}$, Brigitte Zimmerman ${ }^{\mathrm{d}}$ \\ ${ }^{a}$ Department of Political Science, University of California, San Diego \\ ${ }^{b}$ Center for Marine Biodiversity and Conservation, Scripps Institution of Oceanography \\ ${ }^{c}$ Corresponding author. Email: nobradovich@ucsd.edu. Address: 322 Social Sciences, 9500 Gilman Drive, La Jolla, CA 92019 \\ ${ }^{d}$ Department of Public Policy, University of North Carolina, Chapel Hill
}

\begin{abstract}
Will African voters support climate change policies? By 2020, the United Nations' Green Climate Fund intends to provide tens of billions of dollars per year to African nations to support climate adaptation and mitigation policies. It is widely assumed that African citizens will support implementation of these climate policies. We observe the opposite result. In this article - across two experimental studies - we find evidence that Sub-Saharan African politicians who commit to climate change policies may lose electoral support. Electorally important swing voters with weak party affiliations are least likely to support party statements about climate change. Interviews with standing elected officials from Malawi and South Africa corroborate our experimental findings. The combined results suggest voter preferences may hinder the successful implementation of climate change policy in Sub-Saharan African democracies.
\end{abstract}

Keywords: climate policy, climate mitigation, climate adaptation, African politics

\section{"Climate change is not a winning electoral strategy. It's not. Not at all."}

- South African District Councillor

\section{Introduction}

Climate change poses a dire threat to African well-being (Müller et al., 2011; Burke et al., 2009; Lobell et al., 2011). Recognizing this, the United Nations Green Climate Fund intends by 2020 to distribute billions of dollars of climate finance per year to African nations to support climate change adaptation and mitigation policies (van Kerkhoff et al., 2011). These long-run policies are designed to attenuate the severity of climate change's impacts on the continent over the coming decades (Klein and Möhner, 2011). Successfully translating these funds into African climate resiliency is vital.

Unfortunately, there are numerous political barriers to enacting climate change policies on the continent. African democracies are characterized by poor political performance, high levels of corruption, and relatively low levels of political stability (Englebert, 2002). Holding office in Africa tends to be an efficient way for politicians to become wealthy at the expense of their citizenry (De Sardan, 1999). Politicians may simply steal funds earmarked for climate resilience policies for their own use or may allocate these funds only to have them diverted to projects unrelated to climate change or embezzled by subordinates (Blundo et al., 2006; Reinikka and Svensson, 2004). Even if climate resilience funds are successfully allocated by one politician, there is little guarantee that the results of the next election will not see the funds subsequently stripped (Brunner and Enting, 2014). Such politiciandriven corruption is typically cited as the primary challenge to African climate policy implementation (Petherick, 2012).

Depictions like these assume African citizens desire climate policies and that negligent or corrupt politicians might produce failures in policy implementation. However, African voters may not prefer the implementation of policies required to build resilience to a changing climate. The low-levels of economic development on the continent leave the average African living on the equivalent of under five dollars per day (World Bank, 2012). At such low levels of income, short-term needs eclipse future considerations (Holden et al., 1998). These harsh economic realities have led to an African electoral politics characterized by the provisioning of immediate benefits - rather than policy promises - in exchange for votes (Vicente and Wantchekon, 2009). Gifts of corn, rice, chickens, and tshirts buy votes in many African elections (Bratton, 2008). When the finite resources in African democracies are targeted to providing immediate benefits, fewer resources remain for longer-run policy implementation. These factors combine to make campaigning on and enacting policies with widespread and long-term benefits a poor political strategy in many African democracies (Englebert, 2002) (for more detail see Supplementary Information (SI): Policy and Elections in Africa).

Here we report on the results from two experimental studies combined with data from interviews with standing African politicians. We draw the first set of results from 
large-scale campaign-related surveys we conducted in four districts of Malawi on the day prior to the country's 2014 presidential and parliamentary elections. The second set of results come from - to our knowledge - the inaugural use of Amazon's Mechanical Turk (MTurk) to study African political attitudes. We draw our qualitative data from interviews with office-holding Malawian and South African politicians.

With the data from these studies we examine four questions. First, might African voters reward politicians who emphasize climate change policies? Second, which voters - strong partisans or electorally important swing voters - are most affected by climate change policy messaging? Third, does including climate change policy as one item on a menu of other important policies on their policy platform increase support for African politicians? Fourth, do African voters believe that politicians espousing climate change policy are more likely to win office than those without climate policy platforms? Finally, we intersperse interview data throughout the following sections to examine African politicians' opinions on each of the above questions.

\section{Voter support for climate policy platforms}

\section{"Most people in Malawi don't know much about climate change. If you talk of cli- mate change, you are guaranteed to lose votes."}

\section{- Malawian Member of Parliament}

Might African voters reward their politicians for emphasizing climate change policies? To assess this first question, we conducted a large experiment embedded in a survey of Malawian voters on the day prior to Malawi's 2014 presidential and parliamentary elections. The areas of Malawi we selected - highlighted in Figure 1 - represent diverse economic and demographic sectors of Malawi and are highly similar to many areas of other African nations (see SI: Malawi District Descriptions).

If there is an African nation where climate change policy is likely to be politically beneficial, it is Malawi. Malawi is a peaceful nation, elections are generally free and fair, and open political discussion and debate is relatively common (Bratton et al., 2005) (see SI: 2014 Malawian Elections for more details). The country is also highly rural and relies heavily on agricultural income, leaving it likely to be acutely affected by a changing climate (Chinowsky et al., 2014; Morton, 2007).

Our experiment randomly assigned Malawian voters in our survey to receive one of three experimental conditions. Experiments within the context of surveys, or 'survey experiments', randomly assign subjects to distinct information conditions and evaluate differences in responses across these conditions. They are frequently employed in the social sciences (Sniderman et al., 1991; Tomz and

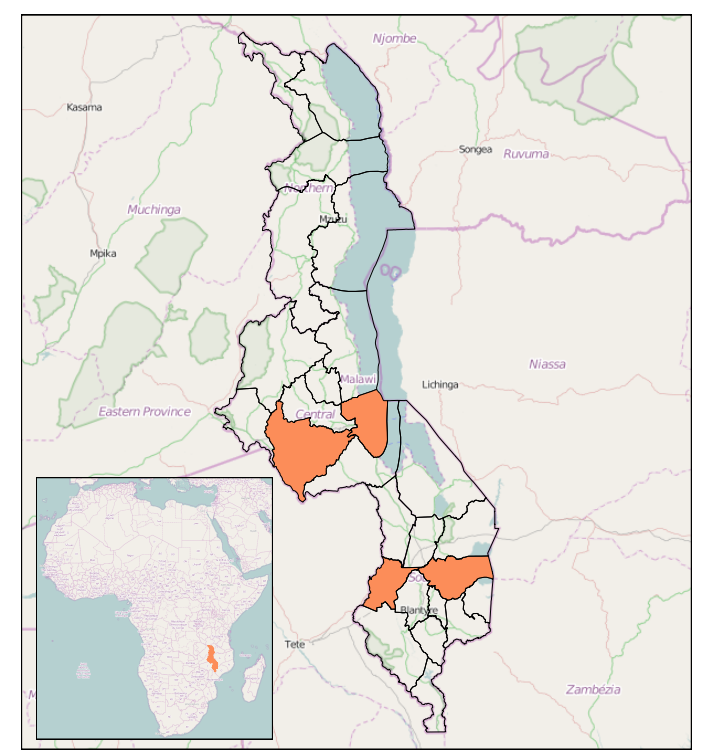

Figure 1: Map of Malawi election study district locations We conducted our Malawi election study across four Malawian electoral districts - Lilongwe, Neno, Salima, and Zomba that vary along demographic, political, and economic factors. These districts provide a broad sampling of Malawian voters (see SI: Malawi District Descriptions).

Van Houweling, 2009) and have been shown to alter both actual and reported behaviors (Berger et al., 2008; Hassin et al., 2007). In our experiment, we randomly assigned each subject to receive either (a) a Short-Run Climate Policy or (b) a Long-Run Climate Policy information condition in the style of common campaign messaging or to receive (c) the Control condition of no additional policy information. We designed our treatments to mimic the style of Malawian parties' campaign messaging surrounding the election. We present the experimental conditions' wording, delivered in Malawi's Chichewa language, below.

\section{Short-Run Climate Policy "Climate change makes farming harder, harming all Malawians. [Respondent's preferred party] will immediately assist struggling farmers."}

Long-Run Climate Policy "Climate change makes farming harder, harming all Malawians. [Respondent's preferred party] will improve the farming sector to make future farming easier."

Control The control condition received no additional policy information.

Prior to administering the experimental conditions, our enumerators filtered out non-voters, obtained respondents' preferred party, and measured the level of support respondents held for this preferred party - information that is freely given to researchers and polling firms in Malawi (Dionne and Dulani, 2014). After the receipt of treatment, participants were given a handful of intervening questions 


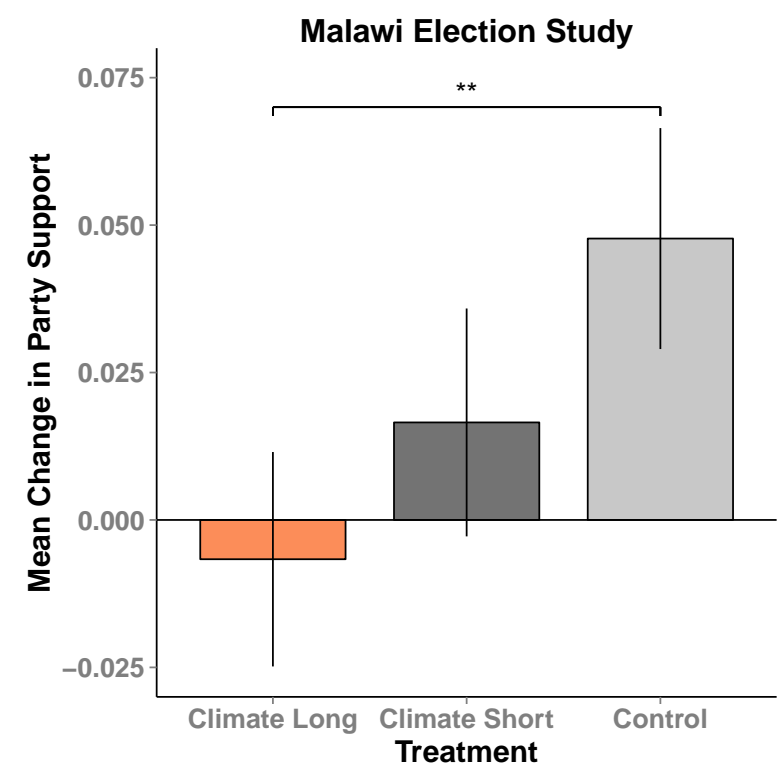

Figure 2: Long-run climate change policy treatment decreases voter support for their preferred party. This figure depicts the mean change in support for respondents' preferred parties pre-treatment to post-treatment across treatment groups in the Malawian 2014 elections study $(n=2,772)$. Error bars are SEM. Two stars indicate significant difference at the $\mathbf{p}=\mathbf{0 . 0 5}$ level. Respondents exposed to the long-run climate change policy platform information had significantly lower changes in support than did the control condition.

to provide distance between the two points at which we measure our outcome variable. On the last question of the survey, participants were again asked how affiliated they felt with their preferred party.

We take the difference in pre-treatment and posttreatment party support as our primary outcome measure. Similar measures of voter support have corresponded closely to actual reported vote choice (Harbridge and Malhotra, 2011; Wilson and Gomez, 2001). We present the language of this question - delivered in Chichewa - below.

Party Support How affiliated are you with [respondent's preferred party]? 1) Indifferent; 2)

Some; 3) A Lot; 4) Very Much; 5) Completely

In the Malawi voter sample $(n=2,772)$, random assignment to the short-run climate change policy party platform produced no significant change in party support compared to the control condition (see Figure 2). However, assignment to the long-run climate change policy party platform produced a significant decrease in average change in party support as compared to the control condition (two-sided t-statistic: 2.083, p-value: 0.037, Cohen's d: 0.10). Thus, informing subjects that their preferred parties intended to implement long-run climate adaptation policy pushed respondents to express less support for their preferred party.

The negative effects associated with the climate policy treatments in the Malawian experiment in Figure 2 are precisely estimated and small in magnitude. Nonetheless,

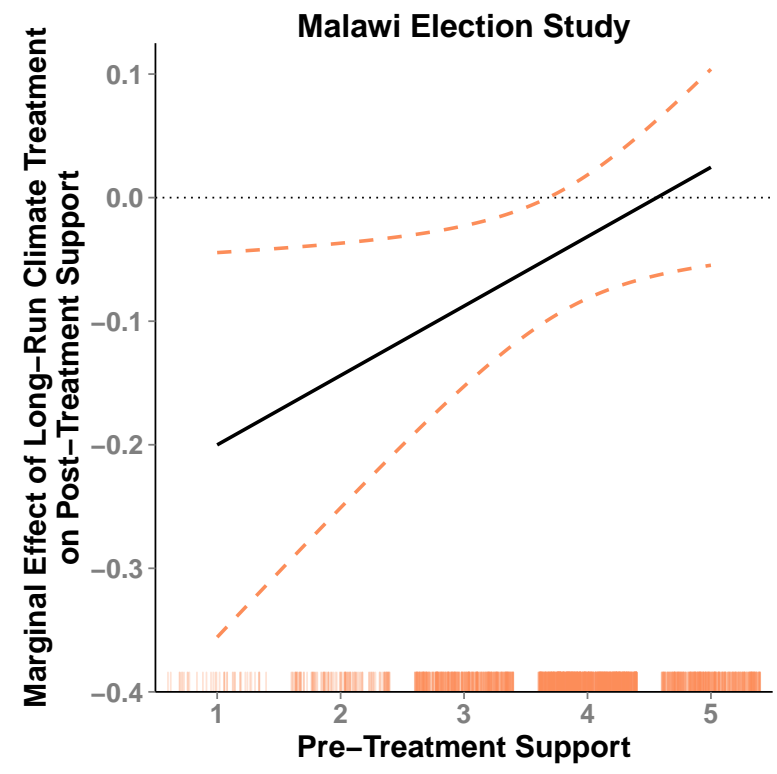

Figure 3: Long-run climate change policy most reduces support among weak party affiliates. This figure depicts the marginal effects from a regression of the interaction between pretreatment party support and long-run climate change policy treatment on the post-treatment level of party support (Berry et al., 2012). Dashed error bars represent 95\% confidence intervals. The rug plot along the $\mathrm{x}$-axis depicts the jittered density of pre-treatment party support measured on a 1-5 discrete scale ("Indifferent" - "Completely"), with 4 ("Very Much") being the median level of pre-treatment support. Marginal effects for weak party supporters are negative while those for strong party supporters are not significantly different from zero.

they are substantively important (Cohen, 1990). A common - if tacit - assumption among policy organizations is that implementation of climate change policy will be supported or even rewarded by African citizens (Godfrey et al., 2012). This assumption, coupled with the fact that our experimental design presented information about what parties proactively intended to do without noting the potential substitution costs of such policy, produces the expectation that our climate policy treatments should have increased party support. Our experimental results clearly indicate that voters did not reward politicians - and may have punished them - for adopting a climate change policy platform within the context of our experiment.

\section{Heterogeneous effects among swing versus core} voters

\section{"Voters won't support the issues that really deal with climate change."}

\section{- South African District Councillor}

Political party attachments are typically stable and can be difficult to sway (Schickler and Green, 1997). As a result, those strongly attached to their preferred party might 
be unlikely to alter their level of support, regardless of the treatment information provided. This fact leads to our second question: which voters - strong partisans or electorally important swing voters - are most affected by climate change policy messages?

To investigate this second question, we interact the longrun climate change treatment with levels of pre-treatment party support to examine the effect of this interaction on levels of post-treatment party support (see Figure 3 ). The results of this regression indicate that voters more weakly affiliated with their preferred party are those most likely to reduce their support for that party when presented with the long-run climate change policy treatment (regression interaction coefficient t-statistic: 2.096, p-value: 0.036) (see SI: Table S1). This fact is important, as weakly affiliated swing voters are vital for parties' electoral contests and parties are unlikely to champion policies that alienate swing voters (Lindberg and Morrison, 2005). Of note, we observe no significant heterogeneous effect of pretreatment party support on the short-run climate change policy treatment. Further, it is important to understand why swing voters may be less supportive of climate policy (Sherley et al., 2014). However, our data indicates that swing voters do not appear to differ significantly from core voters on any of the demographic variables we collected (including age, gender, and farming status).

The results from our Malawi survey experiment combine to suggest that climate change policies - rather than being advantageous to parties - may actually decrease party support and may decrease support most among electorally important swing voters. Malawian politicians, contacted after the election, supported this general conclusion. A ward councillor summarized his thoughts succinctly: "I did not emphasize climate change in my campaign. In Malawi, to win an election you need to talk about issues that affect people daily - like hunger and lack of clean water." This politician awareness was further highlighted by climate change's diminished role within Malawian parties' 2014 campaign policy platforms. For example, the Democratic People's Party, the ultimate winner of the election, mentioned climate change only three times in its over 21,000 word party manifesto, and climate change policy was virtually absent from the political debates surrounding the 2014 election.

\section{Climate change versus other policy priorities}

\section{"I think that - being a developing country - although it's important, climate change is not a priority here. We're still focusing on local issues and trying to do job cre- ation."}

\section{- South African District Councillor}

While our results from Malawi indicate that voters may not reward their politicians for taking up climate change

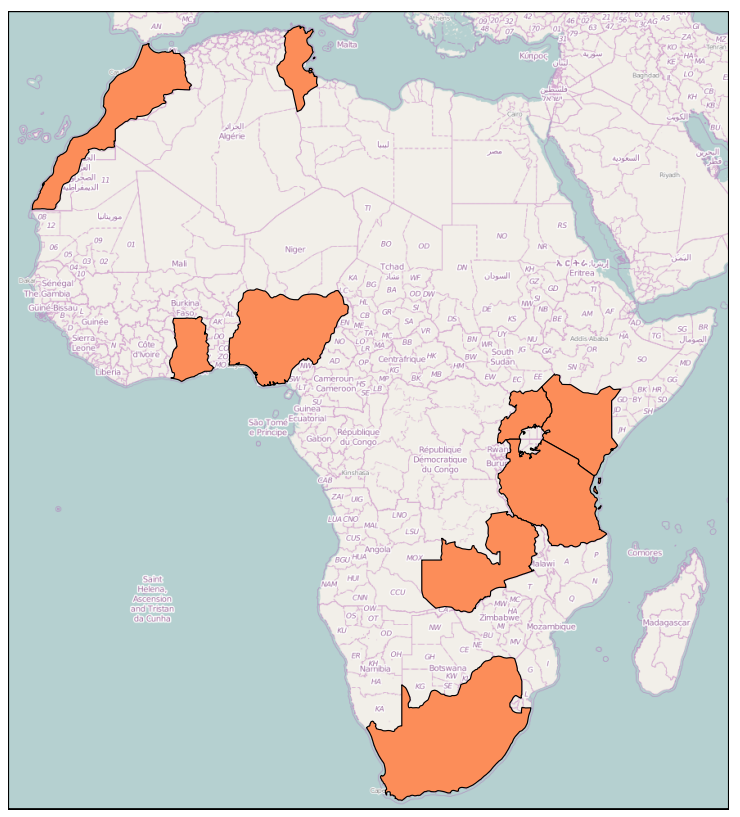

Figure 4: Map of African MTurk respondents' home countries We conducted our MTurk voter experiment with respondents from across ten English-speaking African nations. Respondents from South Africa, Kenya, and Nigeria comprise the majority of the sample and all but two respondents live in Sub-Saharan Africa.

policy platforms, they do not tell us whether or not climate change policy is preferred to other common policy platforms in Africa. This leads to our third question: does having a climate change policy platform as one item on a menu of other important policies increase support for pro-climate African politicians?

To evaluate this question, we employed a new feature of Amazon's MTurk platform - the ability to restrict recruitment to only respondents from Africa - to study the policy preferences of Africans as they relate to climate change. We recruited 86 subjects from ten Englishspeaking African countries in total for the study (see Figure 4 for a depiction of the countries included). The number of subjects recruited is a reflection of the relative novelty of this platform - the size of the African subject pool is not yet large. We believe ours is the first use of this new opportunity to explore Africans' political opinions.

In our experiment, we presented respondents with a simulated election involving two hypothetical candidates, $A$ and $B$ (Kim et al., 2014). In order to control for ballot order effects (Miller and Krosnick, 1998), we presented two distinct elections to our treatment and control groups. The first candidate, candidate $A$, had the same characteristics across each simulated election. In the control condition, subjects were assigned to an election where both candidates, $A$ and $B$, had a platform of three policies randomly chosen from a set of the six most desired policies as indicated by Afrobarometer - a pan-African polling firm (Bratton et al., 2012) - unemployment, education, poverty, 
healthcare, corruption, and sanitation.

In the treatment condition, candidate $A$ again had three policies randomly assigned from the set of six desired policies. However, candidate $B$ had a climate change policy platform: "Will work to address climate change" in addition to two randomly drawn, desired policies. We randomized policy order throughout to eliminate possible policy order effects (see SI: Simulated Election Experiment for experiment wording). After exposure to the platforms of the hypothetical African political candidates, respondents recorded their preferred candidate:

Vote Choice Which candidate would you prefer to vote for?

We take the difference between respondents' desire to vote for candidate $B$ in the treatment versus control condition as our primary outcome measure. In this simulated election, when candidate $B$ campaigned on topics not including climate policy, they received approximately $59 \%$ of the vote share (this deviation from $50 \%$ in the control is likely due to ballot order effects). However when their policy platform included climate change in the treatment election, candidate $B$ 's vote share plummeted to $32 \%$, a large and statistically significant difference (two sided tstatistic: 2.569 , p-value: 0.012, Cohen's d: 0.56). Thus, campaigning on a climate change platform significantly and substantively reduced the vote share won by that candidate as compared to campaigning on one of the alternative policies (see Figure 5, panel (a)).

Of note, our sample of African MTurk respondents is markedly more educated than the median African voter and thus likely to have more informed opinions regarding the threats posed by climate change (Godfrey et al., 2012). Only one of our respondents indicated that they had never previously been exposed to the concept of climate change, $97 \%$ indicated the believed climate change was occurring, and $68 \%$ reported believing that climate change negatively affected their life.

This divergence in our sample's awareness and concern about climate change from the median African voter is important, as lack of knowledge about climate change was a primary reason cited by African politicians for not campaigning on climate change policy. A South African politician stated: "If you speak about climate change to rural voters, you're just speaking Greek - a language that they don't understand. They just can't relate, unless there's an effort to educate them about the importance of climate change." Our simulated election experiment indicates that even when African voters are well-educated about climate change they may still prefer their politicians to focus on policies with more immediate benefits. As a result of this markedly high level of awareness of climate change among our respondents, the vote choice effects we observe in this sample may present a lower bound; less educated African voters may punish pro-climate politicians even more acutely for campaigning on a topic they know little about.

\section{Climate policy and likelihood of electoral suc- cess}

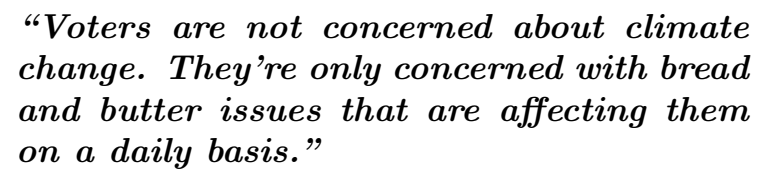

\section{- South African Member of Parliament}

Do our respondents - regardless of their own preference on climate policy - perceive that campaigning on climate change will harm politicians' electoral chances broadly? To examine this question, we asked our respondents their opinion on the chances of the hypothetical politicians winning a national election in their country:

\section{Likely Winner If they were to run for leader of your country, which candidate do you think would win?}

This measure encapsulates' respondents beliefs about how their fellow citizens would respond to politicians' adoption of climate change policy platforms. In our simulated election, when candidate $B$ campaigned on topics not including climate policy, $49 \%$ of respondents projected them to with the election (see Figure 5, panel (b)). However when the candidate's policy platform included climate change, only $17 \%$ of respondents projected they would win the election, a large and highly statistically significant reduction (two sided t-statistic: 3.228 , p-value: 0.002, Cohen's d: 0.72). Thus, campaigning on climate policy may be even less popular among Africa's median voters than observed within our sample.

\section{Discussion}

\section{"We never talked about climate change in our campaign. You can't talk about climate change in an election here. Why would you?"}

\section{- Malawian Member of Parliament}

Across two experimental studies we find that African voters are unlikely to reward - and may significantly punish - politicians for campaigning on climate change policy platforms. Respondents also indicated that they believe it is unlikely that pro-climate politicians would win election over candidates campaigning on more common policy issues. Interviews with standing politicians in both Malawi and South Africa corroborate these findings: every politician we interviewed suggested that campaigning on or enacting climate change policy at the expense of focusing on more pressing, immediate concerns could lead to their electoral demise. The quotes interspersed throughout this article represent a sampling of these opinions. 

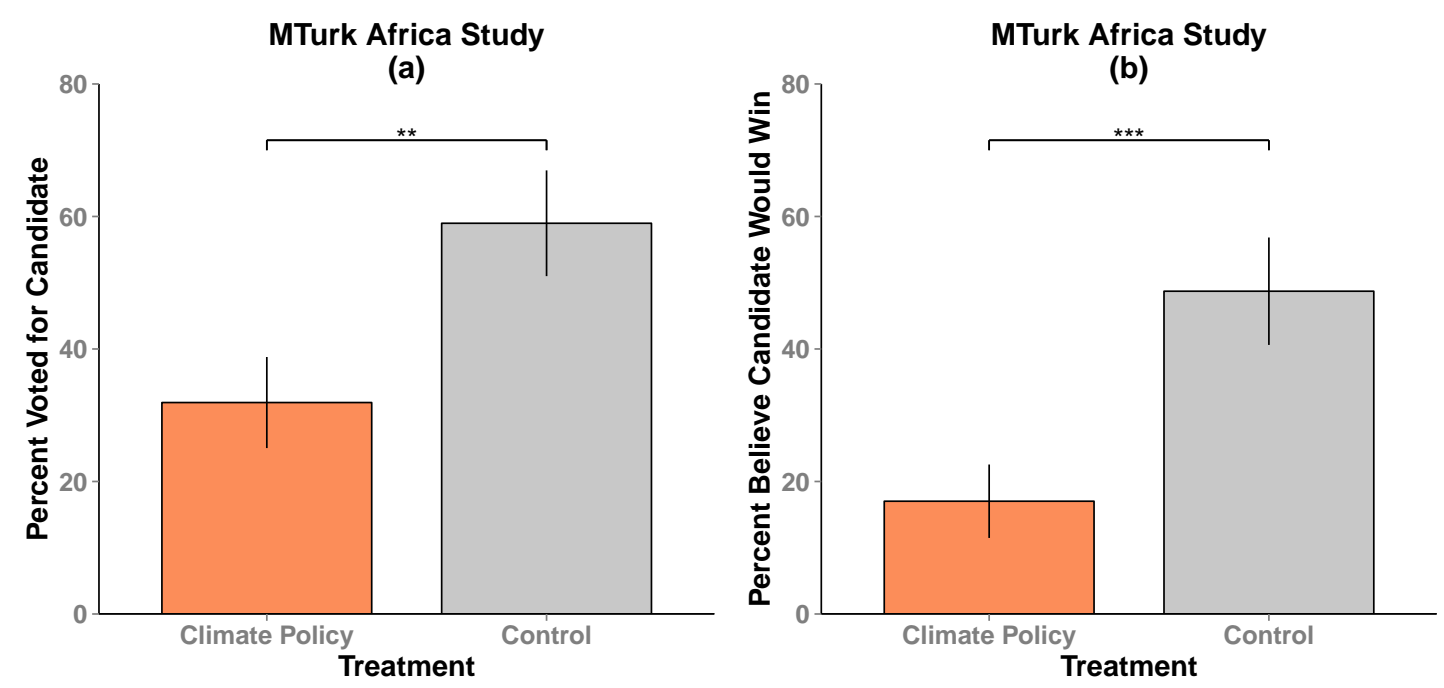

Figure 5: Hypothetical pro-climate African candidates receive fewer votes and are perceived as more likely to lose election. Panel (a) depicts the mean percentage of respondents' vote received by hypothetical candidates $(n=86)$. In the control task, respondents chose between two candidates with three randomized policy platforms that did not include climate change policy. The treatment task presented one of the candidates as supporting climate change policy as one of their three policy platforms. Panel (b) presents the mean percentage of respondents' belief that the candidates would win the hypothetical election. Error bars are SEM. Three stars indicate significant difference at the $p=0.01$ level.

There are a number of reasons why campaigning on climate policies could be electorally costly to African politicians. The first might be that African voters have more pressing economic needs and expect their politicians to provide clientelistic benefits addressing these immediate needs, a concern relayed by politicians. Or - as evidenced by our MTurk experiment - even if voters do care about both longer-run policy and the threats posed by climate change, climate change policy may be low on the list of policy priorities. This could be due to a lack of knowledge of the likely severity of climate impacts (Jeffries, 2014) or because voters prefer politicians to focus on other policy priorities like corruption abatement or education.

While the combined results of our studies suggest the existence of significant political hurdles to the implementation of climate policy in Sub-Saharan African nations, our findings are subject to a handful of limitations and future studies may expand on these results in useful ways. First, our samples, while diverse, are not representative of Malawi or South Africa in particular nor of Sub-Saharan Africa in general. Future studies could examine the external validity of our findings when applied to contexts outside of our samples. Second, our Malawi experiment was not able to fully disentangle whether climate change policy was less appealing to voters as compared to other similar large-scale policy programs on other topics. Future studies should investigate the relative importance of the time horizon of climate policy as contrasted against the same time horizons associated with non-climate policies. Third, our Malawi experiment collected limited covariate information on voters. Future studies should collect additional voter information, specifically on swing voters, to better char- acterize the nature of these voters (Sherley et al., 2014). Finally, our MTurk experiment relies on hypothetical candidates with a limited set of policies that make up their policy platform. While the emphasis of few policies mirrors many electoral contexts in Sub-Saharan Africa, it would be instructive to see how our observed treatment effects might vary with the inclusion of more than three policies per candidate.

What are some of the policy implications of our findings? First, it is widely accepted that the primary goal of politicians in democratic nations is to win elections (Mayhew, 1974). For this reason, policies highlighted in electoral campaigns in Africa - if policies are discussed at all - must each bring clear electoral benefits. If African politicians deem that campaigning on climate policy hurts their electoral chances, they will be less likely to pursue such policies at all and may instead divert climate finance funds to other strategies aimed at more effectively winning votes (Petherick, 2012). Thus any attempts to enable African politicians to enact climate policy should consider politicians' need to address the immediate concerns of their voters in addition to longer-run climate threats. Perhaps policy programs that couple funding for long-run climate policies with funding for programs that provide immediate benefits to citizens could prove politically palatable to Sub-Saharan voters. Second, for African politicians who personally desire to implement climate policy, a helpful electoral strategy could include emphasizing some of the immediate co-benefits of climate policy in their country (West et al., 2013). Third, lack of information about climate change threats does not appear to be at the root of the problem, as our MTurk sample was highly informed 
about climate threats. Even in spite of this they did not support climate policies. Thus, a focus on only spreading information about climate change may be ineffective at swaying political opinions on the topic. Finally, and perhaps most importantly, for international policymakers interested in supporting climate change mitigation and adaptation in the subcontinent, it is vital to account for the domestic politics that will determine the success or failure of such policies in developing African nations in the future (Schreurs, 2008). Future studies are needed to investigate the potential of such strategies to successfully alter support for climate policy in Sub-Saharan nations.

Ultimately, if climate change policies do not enable politicians to win votes, then such policies are unlikely to be enacted. From the evidence available, it appears that African voters may not prefer their politicians to focus on climate adaptation policies. It also appears that African politicians are aware of their voters' climate preferences. These facts combine to indicate that domestic African political realities may undermine international attempts to improve African climate resilience.

\section{Methods}

The fieldwork for our Malawi election survey experiment consisted of a month in Malawi spent orchestrating the details of the day-before-election survey. Upon arrival, we hired local enumerator managers recommended by our contacts at the National Statistical Office of Malawi. Our managers assisted us with planning, designing, and translating of the surveys and survey experiments into Chichewa, the primary language of Malawi. Each enumerator manager forward and backward translated each question and treatment to ensure accuracy.

With the assistance of the enumerator managers, we recruited and trained 131 survey enumerators to deploy on the day prior to the election in four different districts of the country - Lilongwe, Neno, Salima, and Zomba. We selected these districts to capture a broad sample of Malawians: urban and rural, varied socioeconomic strata, and diverse local political environments. Our enumerators employed a random walk strategy to recruit passerby voters in public areas throughout these districts, ensuring no subjects would be sampled more than once. In our sample, forty-eight percent of recruited subjects were female, thirty-seven percent were farmers, and the typical age of respondents was between 31 and 45 years.

To conduct the MTurk simulated election experiment, we opted to allow MTurk respondents who recorded their residence as falling within an English-speaking African nation to take our survey. The survey itself was administered via Qualtrics' online survey software platform, and random assignment to experimental condition was performed via Qualtrics' randomization tool.

Our sample size goal for this experiment was 200 respondents. In total, 208 individuals completed some portion of our survey. However, the MTurk platform's loca- tion screening capabilities are limited, as they are based upon self-report. Fortunately, Qualtrics records the country of origin of the IP address of respondents. We were able to use Qualtrics country data to screen out all likely non-African respondents from the sample, leaving 86 respondents whose IP address originated within Africa and who answered our main outcome variables. Non-African respondents in our initial sample were primarily located within the United States.

Finally, to conduct our interviews we followed up via the telephone with twelve politicians whose contact information we had garnered over the course of our fieldwork in Malawi and South Africa, respectively. In these interviews, we questioned politicians on their opinions regarding the likely success of climate change policies in their countries, and whether or not they would consider campaigning on climate change in upcoming elections. These interviews averaged ten minutes in length.

\section{Acknowledgments}

This work was supported by the National Science Foundation (Grant Nos. DGE0707423, 0903551, and 1424091 to N.O. and 1000107731 and 1160515 to B.Z.) and by the Center for Effective Global Action (to N.O. and B.Z.). We thank B. Chimatiro and J. Mkandawire for their fieldwork assistance and J. Burney, K. Ferree, C. Gibson, D.A. Hughes, R. Migliorini, and members of the UCSD Human Nature Group for their helpful comments.

\section{References}

Berger, J., Meredith, M., Wheeler, S. C., 2008. Contextual priming: Where people vote affects how they vote. Proceedings of the National Academy of Sciences 105 (26), 8846-8849.

Berry, W. D., Golder, M., Milton, D., 2012. Improving tests of theories positing interaction. The Journal of Politics 74 (03), 653-671.

Blundo, G., Olivier de Sardan, J.-P., Bako Arifari, N., Tidjani Alou, M., 2006. Everyday corruption and the state: citizens and public officials in Africa.

Bratton, M., 2008. Vote buying and violence in Nigerian election campaigns. Electoral Studies 27 (4), 621-632.

Bratton, M., Bhavnani, R., Chen, T.-H., 2012. Voting intentions in Africa: ethnic, economic or partisan? Commonwealth \& Comparative Politics 50 (1), 27-52.

Bratton, M., Mattes, R., Gyimah-Boadi, E., 2005. Public opinion, democracy, and market reform in Africa. Cambridge Univ Pr.

Brunner, S., Enting, K., 2014. Climate finance: A transaction cost perspective on the structure of state-to-state transfers. Global Environmental Change 27, 138-143.

Burke, M. B., Lobell, D. B., Guarino, L., 2009. Shifts in African crop climates by 2050 , and the implications for crop improvement and genetic resources conservation. Global Environmental Change 19 (3), 317-325.

Chinowsky, P. S., Schweikert, A. E., Strzepek, N. L., Strzepek, K., 2014. Infrastructure and climate change: a study of impacts and adaptations in Malawi, Mozambique, and Zambia. Climatic Change, 1-14.

Cohen, J., 1990. Things I have learned (so far). American psychologist 45 (12), 1304.

De Sardan, J., 1999. A moral economy of corruption in Africa? The Journal of Modern African Studies 37 (01), 25-52. 
Dionne, K. Y., Dulani, B., May 2014. On the eve of Malawi's election. Online.

URL http://www.washingtonpost.com/blogs/monkey-cage/

wp/2014/05/19/on-the-eve-of-malawis-election/

Englebert, P., 2002. State Legitimacy and Development in Africa. Lynne Rienner Publishers.

Godfrey, A., Burton, M., LeRoux-Rutledge, E., 2012. Africa Talks Climate. Wiley Online Library.

Harbridge, L., Malhotra, N., 2011. Electoral incentives and partisan conflict in congress: Evidence from survey experiments. American Journal of Political Science 55 (3), 494-510.

Hassin, R. R., Ferguson, M. J., Shidlovski, D., Gross, T., 2007. Subliminal exposure to national flags affects political thought and behavior. Proceedings of the National Academy of Sciences 104 (50), 19757-19761.

Holden, S. T., Shiferaw, B., Wik, M., 1998. Poverty, market imperfections and time preferences: of relevance for environmental policy? Environment and Development Economics 3 (01), 105-130.

Jeffries, E., 2014. Blind spot. Nature Clim. Change 4(7), 530-531.

Kim, N., Krosnick, J., Casasanto, D., 2014. Moderators of candidate name-order effects in elections: An experiment. Political Psychology.

Klein, R. J., Möhner, A., 2011. The political dimension of vulnerability: implications for the Green Climate Fund. IDS Bulletin $42(3), 15-22$

Lindberg, S. I., Morrison, M. K., 2005. Exploring voter alignments in Africa: core and swing voters in Ghana. The Journal of Modern African Studies 43 (04), 565-586.

Lobell, D., Bänziger, M., Magorokosho, C., Vivek, B., 2011. Nonlinear heat effects on African maize as evidenced by historical yield trials. Nature Climate Change 1 (1), 42-45.

Mayhew, D. R., 1974. Congress: The electoral connection. Yale University Press.

Miller, J. M., Krosnick, J. A., 1998. The impact of candidate name order on election outcomes. Public Opinion Quarterly, 291-330.

Morton, J. F., 2007. The impact of climate change on smallholder and subsistence agriculture. Proceedings of the National Academy of Sciences 104 (50), 19680-19685.

Müller, C., Cramer, W., Hare, W., Lotze-Campen, H., 2011. Climate change risks for African agriculture. Proceedings of the National Academy of Sciences 108 (11), 4313-4315.

Petherick, A., 2012. A note of caution. Nature Climate Change 2 (3), 144-145.

Reinikka, R., Svensson, J., 2004. Local capture: evidence from a central government transfer program in Uganda. The Quarterly Journal of Economics, 679-705.

Schickler, E., Green, D. P., 1997. The stability of party identification in Western democracies results from eight panel surveys. Comparative Political Studies 30 (4), 450-483.

Schreurs, M. A., 2008. From the bottom up local and subnational climate change politics. The Journal of Environment \& Development 17 (4), 343-355.

Sherley, C., Morrison, M., Duncan, R., Parton, K., 2014. Using segmentation and prototyping in engaging politically-salient climatechange household segments. Journal of Nonprofit \& Public Sector Marketing 26 (3), 258-280

Sniderman, P. M., Piazza, T., Tetlock, P. E., Kendrick, A., 1991. The new racism. American Journal of Political Science, 423-447.

Tomz, M., Van Houweling, R. P., 2009. The electoral implications of candidate ambiguity. American Political Science Review 103 (01), 83-98.

van Kerkhoff, L., Ahmad, I. H., Pittock, J., Steffen, W., 2011. Designing the Green Climate Fund: how to spend $\$ 100$ billion sensibly. Environment 53 (3), 18-31.

Vicente, P. C., Wantchekon, L., 2009. Clientelism and vote buying: lessons from field experiments in African elections. Oxford Review of Economic Policy 25 (2), 292-305.

West, J. J., Smith, S. J., Silva, R. A., Naik, V., Zhang, Y., Adelman, Z., Fry, M. M., Anenberg, S., Horowitz, L. W., Lamarque, J.-F., 2013. Co-benefits of mitigating global greenhouse gas emissions for future air quality and human health. Nature climate change
$3(10), 885-889$

Wilson, M. J., Gomez, B. T., 2001. Political sophistication and economic voting in the American electorate: A theory of heterogeneous attribution. American Journal of Political Science 45 (4), 899-914.

World Bank, 2012. World development indicators 2012. World Bank Publications.

\section{Vitae}

Nick Obradovich has research interests that include climate change politics and policy and the human impacts of climate change.

Brigitte Zimmerman has research interests that include African politics, the political economy of development, and corruption. 